\title{
Brexit and Global Wealth Chains
}

\author{
Seabrooke, Leonard; Wigan, Duncan
}

Document Version

Accepted author manuscript

Published in:

Globalizations

DOI:

10.1080/14747731.2017.1330987

Publication date:

2017

License

Unspecified

Citation for published version (APA):

Seabrooke, L., \& Wigan, D. (2017). Brexit and Global Wealth Chains. Globalizations, 14(6), 820-829.

https://doi.org/10.1080/14747731.2017.1330987

Link to publication in CBS Research Portal

\section{General rights}

Copyright and moral rights for the publications made accessible in the public portal are retained by the authors and/or other copyright owners and it is a condition of accessing publications that users recognise and abide by the legal requirements associated with these rights.

Take down policy

If you believe that this document breaches copyright please contact us (research.lib@cbs.dk) providing details, and we will remove access to the work immediately and investigate your claim. 


\section{Brexit and Global Wealth Chains Leonard Seabrooke and Duncan Wigan}

Journal article (Accepted version)

Cite: Seabrooke, L., \& Wigan, D. (2017). Brexit and Global Wealth Chains. Globalizations, 146), ८२0-8२9. ๑O।: 10.1080/14747731.2017.1330987

This is an Accepted Manuscript of an article published by Taylor \& Francis in Globalizations on 31 May 2017, available online: http://www.tandfonline.com/10.1080/14747731.2017.1330987

Uploaded to CBS Research Portal: January २019 


\title{
Brexit and Global Wealth Chains
}

\author{
Leonard Seabrooke and Duncan Wigan, Copenhagen Business School
}

Bio:

Leonard Seabrooke is Professor of International Political Economy and Economic Sociology at the Copenhagen Business School. His most recent book is Global Tax Battles (co-authored with Duncan Wigan, Oxford University Press, 2019). He is currently working on networks of influence in economic policy design, especially on taxation, finance, and demographic change issues.

Duncan Wigan is Associate Professor of International Political Economy at Copenhagen Business School. He is co-editor (with Leonard Seabrooke) of 'Global Wealth Chains: Asset Strategies in the World Economy' (Oxford University Press, 2019). His research focuses on issues of international taxation and finance.

\section{Abstract:}

One vision of a post Brexit Britain is of a political economy sustained by highly flexible labour markets, light touch regulation and a hyper competitive low tax regime. This article focuses on the tax element, evaluating the prospects of this vision's realisation on the basis of the attributes of the British political economy, the substance of the Britain's new found freedoms and the forces at play in the European and international regulatory environment. Britain is seeking a smooth transition via a strategy of upgrading and expanding national position in global wealth chains. Occupying space in global wealth chains requires a series of careful balancing acts between making a tax offer attractive to mobile capital and maintaining revenue, designing a low tax regime and staying within the boundaries of accepted practice established by multilateral rules and norms, and between multiple, often conflicting, goals that Britain must simultaneously pursue as it leaves the European Union. With hard Brexit, Britain will pursue this vision, but these balances are likely to prove illusive.

Keywords: Global Wealth Chains, Taxation, Brexit, European Union, OECD, Britain

\section{Introduction}

One vision that has animated political and public imaginations of a post-Brexit Britain is that of a lean free market economic fighting machine built on highly 'flexible' labour markets, light touch regulation and a hyper competitive low tax regime. It is a vision that foresees a Britain much akin to former colonial territories such as Hong Kong and Singapore, an offshore financial centre serving as touchdown platform for mobile capital in the hands of corporations and wealthy elites. In conversation with the German newspaper Welt Am Sonntag, Philip Hammond, UK Chancellor of the Exchequer, threatened that the UK would choose this path if it did not secure a favourable exit deal:

If we have no access to the European market, if we are closed off, if Britain were to leave the European Union without an agreement on market access, then we could suffer from economic damage at least in the short-term. In this case, we could be forced to change our economic model and we will have to change our model to regain competitiveness. And you can be sure 
we will do whatever we have to do. The British people are not going to lie down and say, too bad, we've been wounded. We will change our model, and we will come back, and we will be competitively engaged. (Hammond, 2017).

Theresa May was quick to double down on the threat, stating through her official spokeswoman, 'We would want to remain in the mainstream of a recognizable European-style taxation system, but if we are forced to do something different if we can't get the right deal then we stand ready to do so' (LA Times, 2017). It would seem that this iteration of the 'Hayekian dream' (see Worth, 2014) chimes with a large part of the Brexit constituency with a poll finding that $36 \%$ of respondents supported the idea of Britain competing with the EU on tax and $22 \%$ opposed (TJN, 2017). These are the opening salvos of a major skirmish in on-going and recently intensified 'global tax battles' (Seabrooke and Wigan, 2019). The 2008 global financial crisis (GFC) spurred seemingly strong multilateral commitment to tackle the problem of harmful tax competition with a $\mathrm{G} 20$ communique announcing the intention 'to take action against non cooperative jurisdictions, including tax havens' (G20, 2009: 4) and the G8 announcing at Lough Erne a commitment to country-by-country reporting for corporations, the automatic exchange of tax information between national authorities on bank accounts, and full transparency with regard to the beneficial owners of companies and trusts (G8, 2013).

Since the GFC, a host of policy innovations have been launched with the aim of curbing 'global tax battles', starting with the United States acting unilaterally on tax evasion with the Foreign Account Tax Compliance Act and more recently the Organization of Economic Cooperation and Development (OECD) completing avoidance work with the Base Erosion and Profit Shifting initiative (OECD, 2015; Palan and Wigan, 2014). The European Union has been particularly active on the issue reinforcing its armoury against tax avoidance and evasion and continuing to pursue a major overhaul of the corporate tax system in the form of a Common Consolidated Corporate Tax Base (CCCTB). It is in this context of invigorated regulatory activism that the prospect of a post Brexit Britain committed to a strategy of tax war should be evaluated. Morgan notes, 'The temptation will be to pursue policies advantageous to rising profit shares: that is, allowing more wealth capture from wealth creation. Typical means to these ends include: lowering corporation tax... modern corporations operate long supply chains with complex production processes in different locales. Being outside of a trading bloc disrupts one's capacity to be part of the chain. This is likely to intensify the need for concessions to attract corporate investment, and also further a temptation to attract reporting of revenues rather than actual economic activity-a tax haven effect' (2014: 122-123). In a corner Britain promises to come out fighting with the sovereign capacity to write tax law.

One way of thinking about Britain's tax competition exit strategy is through the concept of 'global wealth chains' (GWCS). The work on GWCs provides a systematic way to view how accounting, finance, law, and regulatory governance interact to produce five different ideal types of how wealth is created and protected in multi-jurisdictional environments (Seabrooke and Wigan 2014, 2017). The purpose of GWC research is to understand corporate form, taxation issues, and regulatory arbitrage opportunities as a system rather than as discrete topics within their own silos. In this manner GWCs research draws on Global Value Chains research (cf. Gereffi, 1994; Gereffi et al., 2005) that depicts the journey of a commodity through an internationally dispersed production process conditioned by a series of buyer and supplier relationships. Global wealth chains complements its 
focus on who does what in global production, by following the money. Mirroring work by Gereffi et al. (Ibid.), the GWC frame distinguishes five ideal types of chain - market, modular, relational, captive and hierarchy - on the basis of relations between clients, suppliers and regulators, with the state often playing a dual role as both supplier and regulator (Seabrooke and Wigan, 2017; Finér and Ylönen 2017). The framework also permits insights into the sources of global inequalities (Quentin 2017).

Which chain a particular service or product is situated in is a function of the complexity of information and knowledge regarding the product or service being supplied, the liability of the service or product to regulatory intervention, and the capabilities of suppliers to furnish solutions to fend off challenges to the product or service by regulators (Seabrooke and Wigan 2017). Market chains for example will involve arms length transactions and simple off the shelf products such as offshore shell companies, with the client shielded from the regulator by secrecy provided by the supplier. Relational chains include private wealth managers who closely coordinate with clients, often High Net Worth Individuals, to provide more complex multijurisdictional investment solutions that regulators find difficult to track. Hierarchy chains involve the most complex products, including structured finance and corporate reorganisations, where close coordination, or complete integration, between client and supplier ensure the regulator has little capacity to intervene (ibid.). Despite David Cameron's Lough Erne announcement and accelerated regulatory innovation noted above, the threat of a tax war exit strategy promises that a post Brexit Britain will play an even greater role in maintaining and operating global wealth chains, exporting to Europe the symptoms of a tax curse as it has in the past exported those of a 'finance curse' (Christensen et al., 2016). Britain certainly occupies a position in the world economy that indicates this is a credible threat.

\section{The Battle Field}

The role of Britain in GWCs has a long lineage. The emergence of the Euro dollar and bond markets in London between 1957 and 1961, effectively created an infrastructure for offshore 'global' finance in the heart of the Bretton Woods system, placing trades between non-residents outside the regulatory net; and marking 'a fundamental shift in international financial relations, from one directed towards the furtherance of distinct 'national' regimes of accumulation, based on a system that was almost wholly regulated, to one that is today mostly responsive to the demands of global speculation and almost wholly unregulated' (Burn, 1999: 226). At the same time, UK authorities were often active in the process whereby many of its former colonial possessions used powers afforded by frequently partial independence to pursue an offshore strategy, with the Bank of England and Ministry of Overseas Development sometimes pitted against the Inland Revenue and Treasury in the face of an emergent 'British tax haven empire' (Sagar et al., 2013).

The British offshore imprint is substantial. Haberly and Wójcik suggest with regard to Foreign Direct Investment (FDI) that of the approximately '30-50 percent of global FDI accounted for by networks of offshore shell companies created by corporations and individuals for tax and other purposes' the metropolitan core of the former European colonial system is, 'clearly the centre of the global offshore network, with Britain's offshore second empire of singular importance' (2015: 251, 272). London is the key hub in this network with capital channelled from the second empire, facilitated 
by a shared common law tradition. This legal tradition permits ample amounts of what Sol Picciotto refers to as legal indeterminacy, an indeterminacy that empowers legal elites to facilitate wealth chains by keeping the regulator at bay with linguistic word play and normative judgements over what exactly tax law means (Picciotto 2015). Brexit empowers this aspect of London-focused financial capitalism and the likelihood of Britain becoming even more like a 'tax haven'. The power of judges and lawyers to guard against regulators infringing on different legal structures that underpin wealth chains is well known, and highly protected (Quentin 2019).

The Tax Justice Network produce a Financial Secrecy Index (FSI) which compares the offshore footprint of jurisdictions according to the level of secrecy provided to international capital and holders of capital weighted by a jurisdiction's share in global financial services exports. According to the 2015 FSI Britain taken alone ranks fifteenth in the world on the basis of the size of its hold in global financial markets (TJN, 2015). Taken together with its Crown Dependencies and Overseas Territories, such as Jersey, the Caymans Islands and the Isle of Man, Britain would top TJN's list of secrecy jurisdictions. Given legal control over Crown Dependencies, Overseas Territories and Commonwealth countries - for each London's privy council is the ultimate legal authority - Britain's offshore network would seem to offer an ideal institutional basis from which to wage its tax battle and make a claim on a greater share of the business conducted through global wealth chains.

At the same time the United States has occupied a much more aggressive battle position since the election of Donald Trump. The implementation of the Foreign Account Tax Compliance Act has unfolded in such a way as to exclude partner countries from the potential benefits of receiving information on the bank accounts of its nationals. Trump has also committed to slash the U.S. headline corporate tax rate of $35 \%$ to $15 \%$, introduce a territorial tax system in the U.S. which would only tax U.S. multinationals on income generated in United States, and provide a repatriation holiday allowing the $\$ 2.5$ trillion accrued by Fortune 500 firms offshore to return at a preferential tax rate (USPIRG, 2016; White House, 2017). A roll back on the tax transparency provisions in the 2010 Dodd-Frank Bill and U.S. reluctance to participate in the OECD's multilateral information exchange system suggest the U.S. may join a low tax Anglo-American alliance.

Britain's prospects in this fight could be considered favourable. Hampered by that direct taxation remains a closely guarded EU member state competency and a proposal concerning direct taxes requires unanimity at the Council of Ministers and the de facto revision of the treaties, the European Union long failed to progress on issues of direct taxation (Wigan, 2014). While the Community adopted a significant body of legislation on VAT and excise duties in the early 1990s, this 'only highlighted the absence of a coherent policy on direct taxation' (European Commission 2001: 3). European Union power has traditionally been limited to indirect taxes such as VAT and excise duties, seen to hinder aspirations for the single market. However, more recently Algirdas Šemeta and Pierre Moscovici, successively European Commissioners for Taxation and Customs Union, Audit, and AntiFraud, have been more activist with Šemeta on the heels of the G20 declaring war in 2012, 'Let there be no illusion: tax evaders steal from the pockets of ordinary citizens and deprive Member States of much-needed revenue. If we want fair and efficient tax systems, we must stamp out this activity. The political will to intensify the battle is there. Now it is time to translate that into action' (quoted in European Commission, 2012: 1). The prospects of Britain's effort to win market share in global 
wealth chains is in part conditioned by the coherence of European Union policy and concomitant political will to act against British incursions.

The signs point to a Europe more committed to a coherent policy on taxation and less likely to tolerate a Britain acting as offshore satellite. The earlier innovation of the Savings Tax Directive and on-going policy developments within the EU in terms of the update to the Savings Tax Directive, state aid investigations under the authority of the Competition Commissioner Vestager, the Directive on Administrative Cooperation, the incorporation of the OECD's newly minted multilateral Automatic Exchange of Information standard into European regulation, versions of Country-byCountry Reporting (CBCR) in the Capital Requirements Directive IV and the Accounting and Transparency Directives that impact all large multinationals operating in the Union, and the adoption of a directive requiring member states to provide information on the beneficial ownership of companies mean that the European tax regime is evolving rapidly and takes the lead internationally. At the same time the OECD has taken steps to strengthen the multilateral regulatory architecture against tax abuse in its Base Erosion and Profit Shifting initiative, which is promulgating new rules to increase transparency and restrict opportunities for tax arbitrage, including a demand for the automatic exchange of tax information between tax authorities and a form of CBCR by companies (OECD, 2015).

The international tax system (so far as we can usefully nominate one) sits at a juncture, in one direction is increased cooperation and tighter rules, in the other, increased tax competition and greater divergence between nationally circumscribed tax rules. Britain's threat to become a low tax offshore satellite of the European Union in consequence faces countervailing forces. It also faces the apparently weaker hand that Britain holds in negotiating exit terms with the Union. Passporting rights for financial services - the right to sell financial product Europe wide - depends on the acquiescence of Britain's European negotiating partners (cf. Toly, 2017). Initial salvoes in the exit negotiations suggest that Britain will not be given an easy ride, and in choosing a turbo charged tax competition strategy may need to sacrifice other cherished goals, in particular the maintenance of a political economy almost uniquely shaped around London's financial centre (Gifford, 2016: 78485).

\section{The Battle}

Occupying space in global wealth chains requires a series of careful balancing acts between making a tax offer attractive to mobile capital and maintaining sufficient revenue, designing a low tax regime and staying within the boundaries of accepted practice established by multilateral rules and norms, and between multiple, often conflicting, goals that Britain must simultaneously pursue as it leaves the European Union. Ultimately, these balances may prove more illusory than the bravado behind Britain's threat of post Brexit tax war suggests.

VAT has been harmonised in the EU since 1977 due to the barrier to free trade implied by multiple and varied national sales tax regimes. Britain's exit will provide it with free rein in this regard. However, VAT represents a significant portion of Britain's fiscal income, one fifth of the total, and making dramatic cuts to its rate would entail budgetary consequences the Treasury would be 
unlikely to support. Instead, Brexit might see some minor tinkering with the VAT system on one hand to pander to voters (consider the row over the governments wish to remove VAT from women's sanitary products), and on the other to ensure that the British system is sufficiently aligned to that of Europe to avoid costs for UK businesses trading in European countries. Import VAT on goods entering the UK and goods from the UK entering Europe, although recoverable, will add cash flow costs to many businesses. VAT then is not a heavy weapon in the British armoury.

Britain has ostensibly more room for manoeuvre in wealth chain markets built around direct taxation, particularly market and hierarchy chains hosting wealthy individuals and large multinational corporations. On corporate taxation Britain prior to the vote to leave already had journeyed some way down this path. In March 2016, the then Chancellor announced the intention to bring the corporate tax rate down to $17 \%$ by 2020 . Theresa May, in late 2016, promised business leaders to maintain 'the lowest corporate tax rate in the G20' to match Trump's promise of a 15\% rate in the U.S. May's suggestion was warmly welcomed by the former Chancellor, George Osborne, who tweeted, 'Good to see briefing that corporation tax should be cut again. We got it from 28 per cent to 17 per cent. Next step let's go to 15 per cent and show UK open to business' (Houlder, 2016). Notably, this path was well trodden long before the Brexit vote as direct tax rates are a member state competence and successive British governments have sought competitive advantage on the basis of reducing corporate tax levels. It is not beyond imagination that the final destination is a $0 \%$ corporate tax rate with foreign shareholders, and corporate issuers, flocking to London in search of tax enhanced returns. Domestic shareholders may bear the brunt of the cost though, as the revenue that previously came directly from corporates is substituted by revenue coming from British based shareholders (Murphy, 2017). The vulnerability of this strategy lies more in Britain's international reputation with a leaked memo from the OECD stating, 'A further step in that direction would really turn the UK into a tax haven type of economy' (Houlder, 2016).

On point of Brexit, EU Directives and regulation will no longer apply in Britain. The wind blows both ways here. That British companies will no longer be subject to the Parent-Subsidiary and Interest and Royalty Directives is a potential loss for the UK and those companies. These Directives exempt dividend, interest and royalty payments from withholding taxes on intra-Union transfers. After Brexit, member states could apply withholding taxes on these payments to Britain. Britain has a double tax treaty with every member of the European Union and in many cases these treaties eliminate taxes on such payments between signatories. However, not all double tax treaties with member states in place carry provisions that eliminate taxes on these transfers (Mazurs, 2016). Revisions to treaty agreements will depend on member states acceptance of British tax policy more broadly, and its adherence to OECD norms particularly, so that in so far as Britain seeks to leverage an aggressive tax competition strategy member states may be less willing to make concessions on such issues.

On the other hand, release from EU Directives may provide space in which Britain can re-design its tax system in the way envisioned by George Osbourne, Philip Hammond and Theresa May. Release from the strictures of agreement to the Code of Conduct on Business Taxation and the reach of EU competition law, deployed concertedly to curtail perceived egregious tax avoidance by the present EU Competition Commissioner, Margrethe Vestager, affords some room for manoeuvre. The Code of Conduct on Business Taxation is soft law, used in the EU when lack of political consensus blocks 
policy progress. Adopting the code, member states committed to roll back existing tax measures that constituted harmful tax competition and refrain from introducing any further such measures (Cattoir 2006: 3-4). While the code recognizes the benefits of tax competition, it also provides grounds for a shared understanding of harmful competition, requiring the participation of EU dependent territories, and leading to confrontation with jurisdictions seeking to compete by distinguishing between resident and non-resident companies for tax purposes. The removal of the strictures of the Code from Britain and its dependencies ostensibly affords Britain greater freedom in designing its tax system in a way of its own choosing. So too does escape from the reaches of EU Competition law.

Post Brexit, the removal of EU state aid rules and the uncertainty over advanced tax rulings that the Competition Commissioner's activism in this area has generated may provide Britain greater scope in its pursuit of aggressive tax competition. State aid investigations into transfer pricing rulings given to multinational companies such as Starbucks, Fiat, McDonalds and Apple have put a cooler on intraEU tax competition and infamously resulted in a demand that Ireland collects $€ 13$ billion from Apple. This demand is being contested both by the company, and perhaps ironically, by the government under which the revenue authority set to make a windfall gain operates (for the Apple case, see Bryan et al. 2017). In theory then, out of the reach of EU competition regulation Britain could provide state aid to resident companies and offer a host of reliefs, benefits and deductions otherwise not available in the Union. It is important though that the Anti Tax Avoidance Directive passed by the Council in June 2016 foresees the EU compiling a blacklist of non-cooperative third countries, which are susceptible to sanctions. For Britain, if deemed a third country post Brexit, exploiting its new founds freedom may not be costless.

The European Union in the absence of Britain at the table may well be able push further forward on direct taxation issues. The proposed Common Consolidated Corporate Tax Base envisions a formulary apportionment approach to taxing multinational firms operating in Europe. This involves establishing a common tax base or harmonising corporate tax rules across all European jurisdictions and allocating corporate group profits to each member state according to a formula including, for instance sales, labour force and capital. This has the potential to greatly reduce the space corporations have enjoyed to shift profits to low or no tax jurisdictions and losses to high tax jurisdictions via transfer pricing or intra-firm financing (Morgan, 2016; Seabrooke and Wigan, 2016). In so far as this form of tax reporting provides a gauge of what might be a reasonable allocation of profits to Britain by a multinational operating in Europe, such allocations will become open to dispute, and disproportional or diverted profits in Britain may lead member states and the Commission to seek redress through blacklisting on the basis of contravention of OECD norms, particularly those promulgated under the BEPS initiative. Similar retaliation can be expected should Britain backslide on commitments to transparency measures on the beneficial ownership of trusts, a long term British speciality, and an issue that Europe is likely to continue its push forward on given that Britain has long blocked progress.

At the same time, as Britain's loses all influence in Europe its dependencies and overseas territories, an important source of funding for London's financial markets, may become more vulnerable to sanctions from Europe. In the eventuality that Britain pursues an aggressive tax competition strategy member states and the Commission will be incentivised to act decisively against these 
jurisdictions. Having taken a central role in the development of the OECD Base Erosion and Profit Shifting Initiative, which has established a host of new international tax norms, including the automatic exchange of tax information between authorities, country-by-country reporting for corporations and stricter guidelines on the design of financing arrangements, Britain may find it difficult to head full steam in the other direction. 'The tension between tax competitiveness and opposition to tax avoidance will not be removed by Brexit' (Freedman, 2017).

\section{Conclusion}

A post Brexit Britain that follows up on the threats issued by Hammond and May, will be a Britain excluded from the economic benefits of the trade in goods and services with European Union member states, and a Britain facing the atrophy of what is (erroneously) considered the goose the lays the golden eggs, the City of London. Brexiteers dreaming of fighting back with low wages, light regulations and aggressive tax policies are imagining that these benefits can be substituted by corporate and elite wealth flows. Notwithstanding the fact that wealth flows in and of themselves will be insufficient to propel a major political economy and the welfare and employment requirements attendant to that, this is a recipe for long term decline. Wealth flows are by nature fickle and a Britain effectively excluded from its giant neighbouring market will unlikely remain attractive. Large international banks are already relocating staff to Ireland and Luxembourg to capture the European market that will be lost to British business. London's financial pre-eminence attracts global professional services firms, law firms, accounting and taxation specialists. This skills nexus may in turn become fragile and feed back into a frustrated plan. Such a consequence will change how global wealth chains articulated via the City are formed, changing into more and more aggressive forms of tax planning that are veiled in legal indeterminacy. Should that be the case we are going to need some analytical tools to handle this transition as Britain and Europe diverge in how they treat corporate form. Global wealth chains provide a fruitful means of integrating how we understand law, accounting, finance, and regulatory changes as a system. Brexit may concentrate the dependence of London-based elites on these systems even more. Knowing how to unbundle and analyse these networks becomes more important, as relations between suppliers, clients and regulators continue to morph under force of intervention, innovation and political (mal)intent.

\section{References}

Bryan, D., M. Rafferty and D. Wigan (2017) 'Capital unchained: finance, intangible assets and the double life of capital in the offshore world', Review of International Political Economy, 24(1): 56-86.

Burn, G. (1999) 'The State, the City and the Euromarkets', Review of International Political Economy, 6(2): 225-260. 
Cattoir, P. (2006). 'A History of the "Tax Package": The Principles and Issues Underlying the Community Approach', Taxation Papers, Working Paper No. 10.

Christensen, J., N. Shaxson and D. Wigan (2016) 'The Finance Curse: Britain and the World Economy', British Journal of International Relations and Politics, 18(1): 255-269.

European Commission (2001). 'Communication from the Commission to the Council, the European Parliament and the Economic and Social Committee: Tax policy in the European Union - Priorities for the years ahead', $\operatorname{COM(2001)} 260$ final.

European Commission (2012). ' Tackling tax fraud and evasion: Commission sets out concrete measures', June 272012 Press Release IP/12/697, available from http://europa.eu/rapid/press-release_IP-12-697_en.htm (accessed on June 29 2013).

Finér, L. and M. Ylönen (2017) 'Tax-driven Wealth Chains: A Multiple Case study of Tax Avoidance in the Finnish Mining Sector', Critical Perspectives on Accounting, forthcoming, https://doi.org/10.1016/j.cpa.2017.01.002

Freedman, J. (2017) 'Tax and Brexit', Oxford Review of Economic Policy, 33(S1): S79-S90.

G8 (2013) '2013 Lough Erne G8 Leaders' Communique' available at: https://www.gov.uk/government/publications/2013-lough-erne-g8-leaders-communique

G20 (2009) 'Global Plan for Recovery and Reform', Statement Issued by the G20 Leaders, 2 April, London, available from: http://www.cfr.org/financial-crises/g20-global-plan-recoveryreformapril-2009/p19017

Gereffi, G. (1994) 'The organisation of buyer-driven global commodity chains: how US retailers shape overseas production networks' in G. Gereffi and M. Korzeniewicz (eds)

Commodity Chains and Global Capitalism, Westport: Praeger, pp. 95-122.

Gereffi, G., Humphreys, J. and Sturgeon, T. (2005) 'The governance of global value chains', Review of International Political Economy, 12(1): 78-104.

Gifford, C. (2016) 'The United Kingdom's Eurosceptic Political Economy', British Journal of Politics and International Relations 18(4): 779-794.

Haberly, D. and Wójcik, D. (2015) 'Regional blocks and imperial legacies: mapping the global offshore FDI industry', Economic Geography 19(3): 251-80.

Hammond, P. (2017) 'Philip Hammond issues threat to EU partners' Welt Am Sontag, 15 ${ }^{\text {th }}$ January, available at: https://www.welt.de/english-news/article161182946/PhilipHammond-issues-threat-to-EU-partners.html 
Houlder, Vanessa (2016) 'Business wary over further cuts to UK corporation tax' Financial Times, November 21, available at: https://www.ft.com/content/245bde5a-affa-11e6-9c37$\underline{5787335499 a 0}$

LA Times (2017) 'British Prime Minister May signals European Union clean break: 'no half-in, half-out' Los Angeles Times, $16^{\text {th }}$ January, available at: http://www.latimes.com/world/la-fgbritain-brexit-20170116-story.html

Mazurs (2016) 'Brexit: Preparing for Change- The tax implications', June, available at: http://www.mazars.co.uk/Home/News/Latest-news/News-Archive-2016/BrexitImplications-for-global-mobility-management

Morgan, J. (2016) 'Corporation tax as a problem of MNC organizational circuits: The case for unitary taxation', British Journal of Politics and International Relations, 18(2), 463-481.

Morgan, J. (2017) Brexit: Be Careful What You Wish For?, Globalizations, 14(1): 118-126.

Murphy, R. (2017) 'Singapore on Thames' City Political Economy Research Centre, forthcoming.

OECD (2015) 'BEPS 2015 Final Reports', Paris: OECD; available at: http://www.oecd.org/tax/beps-2015-final-reports.htm

Quentin, D. (2017) 'Corporate Tax Reform and "Value Creation": Towards Unfettered Diagonal Re-allocation across the Global Inequality Chain', Accounting, Economics, and Law: A Convivium, forthcoming, DOI 10.1515/ael-2016-0020

Quentin, D. (2018) 'Legal Opinion in Global Wealth Chains', in L. Seabrooke and D. Wigan (eds) Global Wealth Chains: Asset Strategies in the World Economy, Oxford: Oxford University Press, forthcoming.

Palan, R. and D. Wigan, (2014) 'Herding Cats and Taming Tax Havens: The US Strategy of 'Not In My Backyard’ Global Policy 5(3): 334-343.

Picciotto, S. (2015) 'Indeterminacy, complexity, technocracy and the reform of international corporate taxation', Social \& Legal Studies 24(2): 165-184

Sagar, P., J. Christensen and N. Shaxson (2013) 'British Government Attitudes to British Tax Havens: An examination of Whitehall responses to the growth of tax havens in British dependent territories from 1967-75' in Leaman, J. and A. Waris (eds.) Tax Justice and the Political Economy of Global Capitalism 1945 to the present, New York and Oxford: Berghahn Books, pp. 107-132.

Seabrooke, L. and D. Wigan (2014) 'Global Wealth Chains in the International Political Economy', Review of International Political Economy, 21(1): 257-263. 
Seabrooke, L. and D. Wigan (2016) 'Powering Ideas through Expertise: Switchmen in Global Tax Battles', Journal of European Public Policy, 23(3): 357-374.

Seabrooke, L. and D. Wigan (2017), 'The Governance of Global Wealth Chains', Review of International Political Economy, 24(1): 1-26.

Seabrooke, L. and D. Wigan (2019) Global Tax Battles: The Fight to Govern Corporate and Elite Wealth, Oxford: Oxford University Press.

TJN (2015) 'Financial Secrecy Index- Narrative Report on the United Kingdom', Tax Justice Network, available at: http://www.financialsecrecyindex.com/PDF/UnitedKingdom.pdf

TJN (2017) 'What does the public think about tax haven plans?' Tax Justice Network, $6^{\text {th }}$ February, available at: http://www.taxjustice.net/2017/02/06/brexit-britain-public-thinktax-haven-plans/

Toly, N. (2017) 'Brexit, Global Cities, and the Future of World Order', Globalizations, 14(1): 142-149.

USPIRG (2016) 'Offshore Shell Games 2016: The Use of Offshore Tax Havens by Fortune 500 Companies', United States Public Interest Research Group, Citizens for Tax Justice, Institute on Taxation and Economic Policy,

Available

at:

http://www.uspirg.org/sites/pirg/files/reports/USP\%20ShellGames\%200ct16\%201.2 FINA $\underline{\text { L.pdf }}$

White House (2017) 'Tax Reform for Economic Growth and American Jobs: The Biggest Individual and Business Tax Cut in American History', The White House: Washington, available at:

http://www.washington.edu/federalrelations/files/2017/04/WHfactsheet04262017.pdf

Wigan, D. (2014) 'Offshore Financial Centres' in Daniel Mügge (ed.) Europe in Global Finance, Oxford: Oxford University Press.

Worth, O. (2017) 'Reviving Hayek's Dream', Globalizations, 14(1): 104-109. 